\title{
p38 MAPK inhibition reduces diabetes-induced impairment of wound healing
}

This article was published in the following Dove Press journal:

Diabetes, Metabolic Syndrome and Obesity:Targets and Therapy 18 June 2009

Number of times this article has been viewed

\author{
Satyanarayana Medicherla' \\ Scott Wadsworth ${ }^{2}$ \\ Breda Cullen ${ }^{3}$ \\ Derek Silcock ${ }^{3}$ \\ Jing $Y \mathrm{Ma}^{\prime}$ \\ Ruban Mangadu' \\ Irene Kerr' \\ Sarvajit Chakravarty' \\ Gregory L Luedtke' \\ Sundeep Dugar' \\ Andrew A Protter' \\ Linda S Higgins' \\ 'Scios Inc., Fremont, CA, USA; \\ ${ }^{2}$ Center for Biomaterials and \\ Advanced Technologies, Somerville, \\ NJ, USA; 3Johnson \& Johnson Wound \\ Management, Gargrave, UK
}

Correspondence: Linda S Higgins InteKrin Therapeutics, Inc, $4300 \mathrm{El}$ Camino Real, Suite 20I, Los Altos, CA 94022, USA

$\mathrm{Tel}+|65094| 550 \mid$

Fax +I 8662862242

Email linda@intekrin.com

\begin{abstract}
In healthy tissue, a wound initiates an inflammatory response characterized by the presence of a hematoma, infiltration of inflammatory cells into the wound and, eventually, wound healing. In pathological conditions like diabetes mellitus, wound healing is impaired by the presence of chronic nonresolving inflammation. p38 mitogen-activated protein kinase (MAPK) inhibitors have demonstrated anti-inflammatory effects, primarily by inhibiting the expression of inflammatory cytokines and regulating cellular traffic into wounds. The $\mathrm{db} / \mathrm{db}$ mouse model of type 2 diabetes was used to characterize the time course of expression of activated p38 during impaired wound healing. The $\mathrm{p} 38 \alpha$-selective inhibitor, SCIO-469, was applied topically and effects on p38 activation and on wound healing were evaluated. A topical dressing used clinically, Promogran ${ }^{\mathrm{TM}}$, was used as a comparator. In this study, we established that $\mathrm{p} 38$ is phosphorylated on Days 1 to 7 post-wounding in $\mathrm{db} / \mathrm{db}$ mice. Further, we demonstrated that SCIO-469, at a dose of $10 \mu \mathrm{g} /$ wound, had a positive effect on wound contraction, granulation tissue formation, and re-epithelialization, and also increased wound maturity during healing. These effects were similar to or greater than those observed with Promogran ${ }^{\mathrm{TM}}$. These results suggest a novel approach to prophylactic and therapeutic management of chronic wounds associated with diabetes or other conditions in which healing is impaired.
\end{abstract}

Keywords: p38 MAPK ihibition, diabetic wound healing, db/db mouse, nonresolving healing, Promogran $^{\mathrm{TM}}$

\section{Introduction}

Chronic wounds are defined as those that fail to heal within an expected time period, and are characterized by impairment of wound closure and contraction rates, reepithelialization and granular tissue formation which is characterized by the presence of chronic nonresolving inflammation. Thus, agents capable of limiting wound inflammation may prove to be effective therapies for chronic wounds. Impaired wound healing is a well-documented phenomenon in diabetes mellitus. ${ }^{1,2}$ Experimental and clinical woundhealing studies have revealed that the hyperglycemic state in diabetes is accompanied by impaired repair capacity at almost all stages of wound healing, including cellular migration, cellular proliferation, tensile strength of collagen, capillary growth, and metabolic activity within the granulation tissue. ${ }^{3}$ Available literature indicates that several phases of the healing process - inflammation, cellular proliferation, matrix formation, and remodeling - are controlled by cytokines and growth factors. The inflammatory cytokine $\mathrm{TNF} \alpha$ is associated with nonresolving inflammation and deficient healing. ${ }^{4-8}$

In diabetes, a delaying factor in wound healing is chronic nonresolving inflammation, but venous and arterial insufficiency and unrelieved pressure contribute 
as well. ${ }^{9,10}$ Although the current treatment in diabetic wound management involves debridement, topical antibiotics, and a state-of-the-art dressing, complications from chronic wounds still arise. Indeed, $60 \%$ of all nontraumatic amputations performed in the United States are a direct result of diabetes. ${ }^{11}$ Development of a more effective treatment for chronic diabetic wounds is imperative. Hinchliffe and colleagues systematically reviewed the effectiveness of interventions to enhance the healing of chronic ulcers of the food in diabetes recently. ${ }^{12}$ In addition, limiting wound inflammation may improve treatment of chronic wounds, and systemic or topical administration of p38 mitogenactivated protein kinase (MAPK) inhibitors have been shown to reduce skin inflammation. ${ }^{13,14} \alpha$-selective p38 MAPK inhibitors such as SD-169, SD-282, and SCIO-469 inhibit the activity of a wide variety of inflammatory cells, including neutrophils, monocytes, macrophages, B and CD4+ $\mathrm{T}$ cells, and endothelial cells. They also limit production of HSP-27, pro-inflammatory cytokines, vascular endothelial growth factors, interleukin-6, tumor necrosis factor- $\alpha$ (TNF $\alpha$ ) and IL-1 $\beta$, as well as TNF $\alpha$ activity and HSP-27 phosphorylation. ${ }^{15-18}$ All of these inflammatory mediators are thought to play essential roles in wounds with nonresolving inflammation and it is worth pursing the therapeutic value of a $\alpha$-selective p38 MAPK inhibitor like SCIO-469 in wound healing settings associated with conditions in which healing is impaired such as type 2 diabetes.

The $\mathrm{db} / \mathrm{db}$ mouse is an animal model of diabetes mellitus, and inflammation-mediated experimental wound progression in the model mimics what is seen in diabetic humans. ${ }^{19,20}$ Accordingly, we used this model to evaluate the efficacy of topical administration of a p38 kinase inhibitor compared to a Johnson and Johnson product used topically for the treatment of chronic wounds. Promogran ${ }^{\mathrm{TM}}$ (oxidized regenerated cellulose/collagen; Johnson and Johnson Medical, Ltd., Ascot, UK) is used clinically as a topical dressing for chronic wounds. It binds matrix metalloproteases and protects growth factors in chronic wound fluid, promoting an environment that attracts cells, supports tissue growth factors, and facilitates tissue granulation. ${ }^{21}$ Hart and colleagues reported delayed healing in diabetic $\mathrm{db} / \mathrm{db}$ mice when compared to their nondiabetic lean littermates $(\mathrm{db} /+)$ and showed that topical Promogran ${ }^{\mathrm{TM}}$ accelerated healing in diabetic $\mathrm{db} / \mathrm{db}$ mice as compared to nondiabetic littermates, ${ }^{22}$ making it an appropriate comparator and positive control.

Since topical administration offers some advantages over the systemic route, such as low risk of systemic toxicity and potentially lower amounts of drug required, we studied topical therapeutic application of the p38 MAPK inhibitor, SCIO-469, at doses of $0.1,1$, and $10 \mu \mathrm{g} /$ wound for 14 days using Promogran ${ }^{\mathrm{TM}}$ as a positive control, and found that SCIO-469 (at $10 \mu \mathrm{g} /$ wound) yielded significant therapeutic benefit in $\mathrm{db} / \mathrm{db}$ mice by day 7 of the treatment (unpublished observations). In the present communication, we report on the involvement of p38 MAPK $\alpha$-signaling in diabetic wounds and describe our results in treating wounds with topical SCIO-469 in diabetic $\mathrm{db} / \mathrm{db}$ mice.

\section{Materials and methods Chemical description of SClO-469}

SCIO-469 is an indole-5-carboxamide and an ATP-competitive inhibitor of p38 kinase. It is a small-molecule, orally active inhibitor of p38 $\alpha$ MAPK (Scios, Inc., Fremont, CA).

\section{SCIO-469 potency and specificity}

SCIO-469 and its structurally and pharmacologically similar analogues SD-282 and SD-169 and have demonstrated anti-inflammatory and arthritis-modifying properties and are known to influence the cytokines involved in inflammatory disorders. ${ }^{15,16}$ They reversibly inhibit kinase activity of p38 MAPK $\alpha$, an intracellular enzyme that mediates cellular responses to inflammatory stimuli. ${ }^{23}$ Inhibitory concentration of $50 \%\left(\mathrm{IC}_{50}\right)$ of SCIO- $469^{24,25}$ against the human p38 MAPKs $(\alpha, \beta, \gamma$, and $\delta$ isoforms) were performed in duplicate using ELISA assays adapted from published methods. SCIO-469 demonstrates $\sim 14$-fold selectivity for $\mathrm{p} 38 \alpha$ MAPK $\left(\mathrm{IC}_{50}\right.$ values of 0.0016 and $0.0011 \mu \mathrm{M}$ ) compared with $\mathrm{p} 38 \beta$ MAPK $\left(\mathrm{IC}_{50}\right.$ values of 0.023 and $0.022 \mu \mathrm{M}$ ), whereas inhibition of p38 $\gamma$ MAPK and p38 $\delta$ MAPK was less than $50 \%$ even at concentrations of $10 \mu \mathrm{M}$. When tested in vitro at a concentration of $10 \mu \mathrm{M}, \mathrm{SCIO}-469$ demonstrated no inhibitory activity against a panel of other kinases, including extracellular signal-regulated kinase 2, c-Jun $\mathrm{NH}_{2}$-terminal kinase-1, and MAPK-activated protein kinase-2. In addition, SCIO-469 demonstrates no effect on the activity of purified cyclooxygenase-1 (COX-1) or COX-2 enzymes.

\section{Dressings and reagents}

Promogran $^{\mathrm{TM}}$, Pad of Release, and Bioclusive Dressing were purchased from Johnson and Johnson Medical Ltd (Ascot, UK). For the phosphorylated p38 measurements, primary rabbit polyclonal antibody was purchased from Santa Cruz Biotechnology (Cat. No. SC-7975-R; Santa Cruz, CA, USA), and the secondary antibody (goat anti-rabbit biotinylated IgG) was purchased from Chemicon International Inc. (Cat. No. AP187B; Temecula, CA, USA). 


\section{Animals}

Diabetic mice (C57BLKs/Bom db/db; B\&M, Denmark) with sustained hyperglycemia (blood glucose $\sim 400 \mathrm{mg} / \mathrm{dl}$ ) for several weeks which are prone to impaired wound healing and their lean littermates or nondiabetic mice (C57BLKs/ Bom db/+; B\&M) aged approximately 16 weeks were used in this study. On the first day of the study period, mice were housed in individual cages in an environment maintained at an ambient temperature of $23{ }^{\circ} \mathrm{C}$ with 12 -hour light/dark cycles. They were provided with food (standard rodent diet) and water ad libitum. All animal procedures were approved by our institutional committee for the care and use of animals in research in accordance with the guidelines of Scios, Inc., USA and Johnson and Johnson Wound Management, UK.

\section{Creation of full thickness experimental wounds}

Mice were anesthetized (isoflurane and air) and shaved. A single, standardized full-thickness wound $(7.5 \mathrm{~mm} \times 7.5 \mathrm{~mm})$ was created in the flank skin of each experimental mouse. Wounds were treated with Promogran $^{\mathrm{TM}}$ (Johnson and Johnson Medical Ltd) applied as $1 \mathrm{~cm} \times 1 \mathrm{~cm}$ squares throughout the study according to manufacturers instructions. All wounds were secondarily dressed with a $1.5 \mathrm{~cm} \times 1.5 \mathrm{~cm}$ Pad of Release (Johnson and Johnson Medical Ltd). The release pad was held in place using a circumferential band of occlusive film dressing (Bioclusive; Johnson and Johnson Medical Ltd). Mice were re-anesthetized, and treatments were reapplied on days 0,1 , 2,4 , and 7 post-wounding. Immediately after wounding and subsequently on days 2,4 , and 7 , all wounds were digitally photographed with a calibration/identity plate. On day 7 of the study, animals were euthanized.

\section{Time-course of phosphorylated p38 levels in wounds}

As described above, a full thickness wound was created on 15 diabetic mice having blood glucose levels around 400 $\mathrm{mg} / \mathrm{dl}$. Wounds were immediately treated topically with 50 $\mu \mathrm{l}$ of citrate buffer at $\mathrm{pH} 4$ (covering a $1 \mathrm{~cm} \times 1 \mathrm{~cm}$ area) to provide moisture to the wound area. This treatment also served as a vehicle control group for the study described in the next section. The wounds were secondarily dressed with a $1.5 \mathrm{~cm} \times 1.5 \mathrm{~cm}$ Pad of Release as described earlier. The bandages were changed on days 4 and 7. At dressing change time points, a few drops of sterile saline were added to dressings as necessary to minimize the occurrence of re-injury. Food was made available after recovery from each procedure. Glucose monitoring was performed on all mice prior to study inception and prior to the day of necropsy. On days $0,1,2,4$, and 7 of the study, three mice per time point were euthanized. Each wound with surrounding normal tissue was excised and subsequently fixed in $10 \%$ formalin for the measurement of phosphorylated $\mathrm{p} 38$ by immunohistochemistry.

\section{Immunohistochemistry}

Immunohistochemical staining for phospho p38 was performed as detailed in our earlier communication. ${ }^{15}$ The primary antibody used in this study was rabbit phospho-p38 polyclonal antibody diluted at 1:50 (Cat. No Sc-7975-R; Santa Cruz Biotechnology). The secondary antibody used for phospho-p38 was goat anti-rabbit biotinylated immunoglobulin G (IgG) (Cat. No. AP187B; Chemicon International, Inc.) diluted at 1:2000, and the negative control in this case was normal rabbit IgG. Phosphop38 immunohistochemistry analysis was evaluated in a blinded manner by the number of the positively stained cells in 10 different regions of the wound, averaged and scored as: $0=$ none; $1=$ mild (around $25 \%$ positively stained cells per field); $2=$ moderate (around 50\% positively stained cells per field); and $3=$ severely (around 75\% positively stained cells per field) positively phosphor-p38 in the wound.

\section{Effect of SCIO-469 on phosphorylated p38 levels in wounds}

In parallel with the p38 phosphorylation studies described above, 15 diabetic mice were wounded as described earlier and treated with SCIO-469. Soon after the wounding, mice received a topical application of $10 \mu \mathrm{g}$ of SCIO-469 in $50 \mu \mathrm{l}$ of citrate buffer at $\mathrm{pH} 4$. Following the application of SCIO-469, wounds were dressed secondarily as described above. Mice were re-anesthetized and SCIO-469 treatment re-applied on days 1, 2, 4, and 7 post-wounding. As described earlier, on days $0,1,2,4$, and 7 , three mice per time point were sacrificed, and wounds were processed for the measurement of phosphorylated p38 as described above.

\section{Effect of SCIO-469 on wound healing in $\mathrm{db} / \mathrm{db}$ mice}

Thirty-two female diabetic mice with blood glucose levels around $400 \mathrm{mg} / \mathrm{dl}$ and eight female nondiabetic mice $(\mathrm{db} / \mathrm{+})$ were wounded as described above. Diabetic mice were divided into four treatment groups as follows: mice in group 1 
were sacrificed soon after the wounding; group 2 received $50 \mu \mathrm{l}$ of vehicle control (citrate buffer, $\mathrm{pH} 4$ ), group 3 received Promogran ${ }^{\mathrm{TM}}$ (positive control); and group 4 received $10 \mu \mathrm{g}$ of SCIO-469 in $50 \mu \mathrm{l}$ of citrate buffer solution topically. Wounds were secondarily dressed as described above. Mice were re-anesthetized, and treatments were reapplied on days 1, 2, 4, and 7 post-wounding. Body weights and blood glucose levels were monitored on days 0 and 7 of the study. On day 7 of the study, mice were euthanized. Their wounds and the surrounding normal tissue were excised and subsequently fixed in 10\% formalin and processed as described above. Eight nondiabetic mice $(\mathrm{db} /+)$ received identical experimental manipulations and treatments.

\section{Photographic assessment for wound closure}

Immediately after wounding and on days 2, 4, and 7, all wounds were digitally photographed with a calibration/ identify plate.

\section{Assessment of wound closure}

Wound assessments were performed at every bandage change, and macroscopic observations of wound healing were recorded as follows: presence and degree of inflammation (slight, moderate, extreme); edema (slight, moderate, extreme); erythema (slight, moderate, extreme); induration (yes, no); amount of exudate (slight, moderate, extreme); wound-bed environment (moist/dry); re-injury (slight, moderate, extreme); and other miscellaneous comments.

\section{Histological assessment of wound healing}

Histological evaluations were undertaken blinded manner on representative hematoxylin and eosin stained sections of each wound. Evaluation parameters included wound width, re-epithelialization, granular tissue formation, and cellular profiles as described below.

\section{Wound width}

Wound width was measured as the distance between normal dermal tissues (wound curvature was taken into account). Three wound-width measurements (from three replicate sections) were taken, and the mean wound width was calculated for each wound (Figure 1A). Image Pro image analysis software (version 4.1.0.0; Media Cybernetics, Bethseda, MA, USA) was used to calculate wound closure from wound images in each of the experimental groups over time.

\section{Re-epithelialization}

Percentage re-epithelialization was measured from three replicate sections of each wound. The extent of neo-epithelial tissue coverage was defined as the distance from the leading edge of the epithelial tongue (over the wound) to the edge of the first intact hair follicle (in marginal tissue). A mean re-epithelialization score was calculated (see below) from three replicate sections.

$$
\% R E-\text { epithelialization }=\times \frac{b+d}{b+c+d}
$$

where " $b+d$ " stands for neo-epithelialized coverage, and " $c$ " stands for nonepithelialized tissue (open wound) (see Figure 1A).

\section{Granulation tissue}

Granulation tissue formation was scored in terms of the volume of the wound void occupied with granulation tissue (Figure 1B). A five-point, semiquantitative scoring system was devised for the purpose of this study with 1 indicating $0 \%$ to $20 \%$ wound void filled with granulation tissue; 2 indicating $20 \%$ to $40 \%$ of wound void filled with granulation tissue; 3 indicating $40 \%$ to $60 \%$ wound void filled with granulation tissue; 4 indicating $60 \%$ to $80 \%$ of wound void filled with granulation tissue; and 5 indicating $80 \%$ to $100 \%$ of wound void filled with granulation tissue. Three replicate sections of each wound were assessed for granulation tissue formation.

\section{Cellular profiles in the wound tissue}

All wounds were assessed in terms of the type of cell predominating within wound tissue (Figure 1C). Cells were classified as either inflammatory cells (eg, neutrophils, macrophages, lymphocytes) or proliferative cells (eg, fibroblasts, endothelial cells) by microscopic examination of tissue slides. The relative contribution of inflammatory and proliferative cells to the cellular population of granulation tissue was scored with the aid of a five-point semiquantitative system with 1 indicating highly inflammatory; 2 indicating predominantly inflammatory; 3 indicating equivalence; 4 indicating predominantly proliferative; and 5 indicating highly proliferative. In addition to being a score of cell type, this scale was read as a score of "wound maturity," with less mature wounds (being primarily populated by inflammatory cells) achieving lower scale readings, and more mature wounds (primarily populated by proliferative cells) achieving higher readings. The score recorded for a given wound reflected the predominant cellular profile of the tissue within the wound void.

\section{Statistical analysis}

Nonparametric analysis (Kruskal-Wallis multivariate analysis followed by an ad hoc two-sample Mann-Whitney U-test 


\section{A}

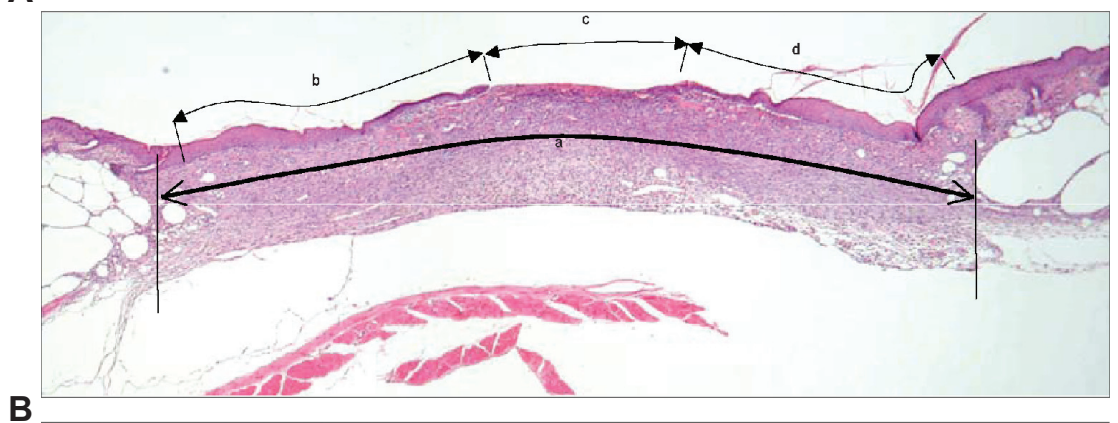

B
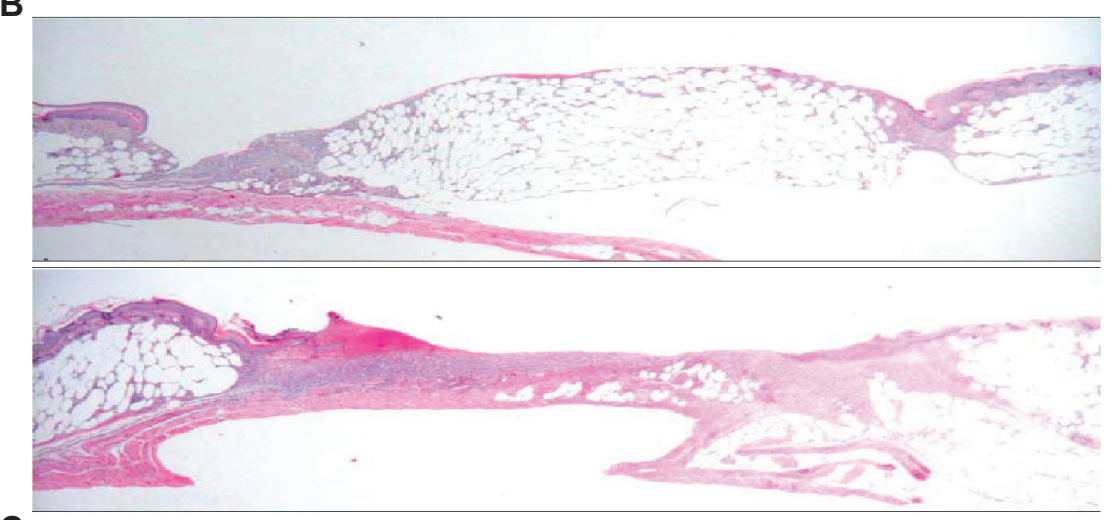

C

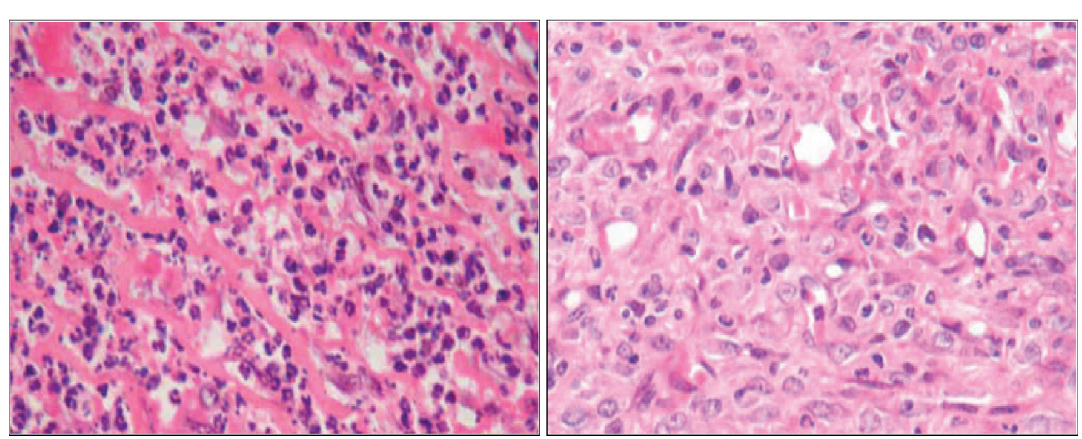

Figure I Histological assessments/scoring methods of wound healing in $\mathrm{db} / \mathrm{db}$ mice. A single, standardized full-thickness wound $(7.5 \mathrm{~mm} \times 7.5 \mathrm{~mm})$ was created in the flank skin of each experimental $\mathrm{db} / \mathrm{db}$ mouse. (A)Wound width measurement method. Wound width was measured as the distance between normal dermal tissues (wound curvature was taken into account) where "a" stands for margin to margin separation (wound width), "b + d" stands for neo-epithelial coverage, and "c" stands for nonepithelialized tissue (open wound). Three wound-width measurements (from three replicate sections) were taken and mean wound width was calculated for each wound. (B) Granular tissue formation: upper panel represents $0 \%$ to $20 \%$ of wound void filled with granulation tissue; lower panel represents $80 \%$ to $100 \%$ of wound void filled with granulation tissue. (C) Cell type or cellularity scoring system. The left panel represents a highly inflammatory condition and the right panel shows a highly proliferative condition.

analysis) was used to test the significance of any intergroup differences in wound closure, re-epithelialization, and granulation tissue deposition. The Student's $t$-test was used to test the significance in cases of phosphorylated p38 measurements.

\section{Results}

\section{p38 was phosphorylated in the wounded skin of $d b / d b$ mice}

Grading of antiphospho-p38-stained wound sections showed that $\mathrm{p} 38$ activation in the wounded skin peaked at days 1 to 2 and then displayed a reduction of phosphorylation (black bars in Figure 2). As compared to unwounded tissue, phospho-p38 increased significantly and peaked on day $1(\mathrm{p}<0.001)$ soon after wounding; it remained at peak plateau levels at day 2 ( $\mathrm{p}<0.001)$, followed by a progressive decrease on days 4 and 7 .

\section{SClO-469 reduced phosphorylated p38 in the wounded skin of $\mathrm{db} / \mathrm{db}$ mice}

Topical application of SCIO-469 reduced the level of phospho-p38 during wound healing in a time dependent manner (cross hatched bars in Figure 2). As in Figure 2, phosphorylated p38 levels increased significantly in the first two days of wound healing when compared to day 0 , and SCIO-469 significantly reduced those levels compared to the vehicle group by day $2(\mathrm{p}<0.001)$. 


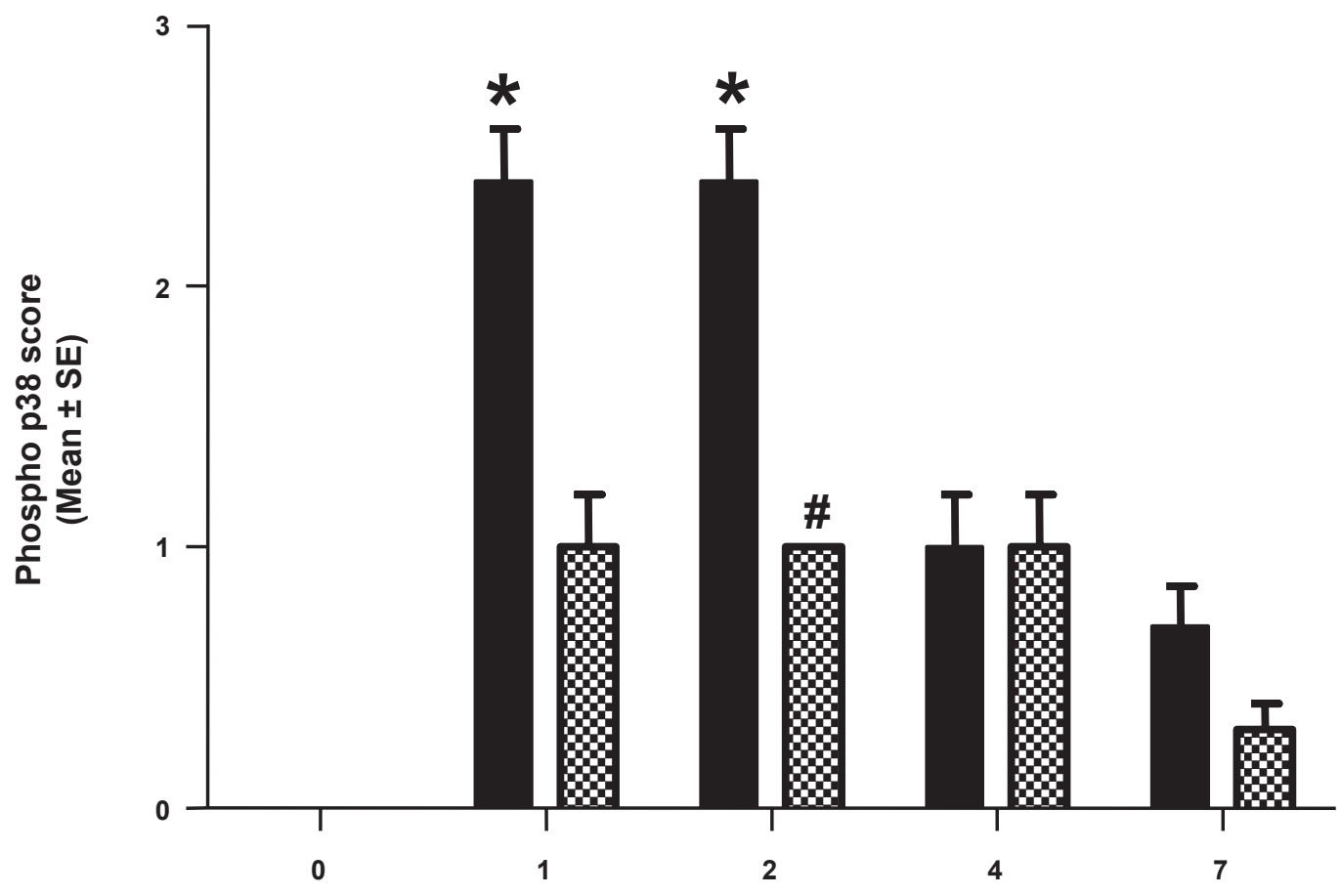

Treatment, days

Figure 2 SCIO-469 reduced phosphorylated p38 in diabetic wounds. Immunohistochemical staining for phospho-p38 (phospho p38). In vehicle treated group, phospho-p38 peaked by day I post-wounding $(\mathrm{p}<0.00 \mathrm{I})$, plateaued by day $2\left({ }^{*} \mathrm{p}<0.00 \mathrm{I}\right)$ and progressively decreased at days 4 and 7 when compared to data collected soon after wounding on day $0 . \mathrm{SCIO}-469$ treatment significantly reduced levels of phospho-p38 on day 2 (\#p $<0.00 \mathrm{I})$. Reductions at day I and day 7 were substantial but not statistically significant. Black bars-vehicle group; cross-hatched bars-SCIO-469, $10 \mu \mathrm{g} /$ wound/treatment. Values are reported as the mean $\pm \mathrm{SE} ; \mathrm{n}=5$.

There was no significant change in body weight in the SCIO-469 treated group when compared to the vehicle control group.

\section{SCIO-469 accelerated wound healing in $\mathrm{db} / \mathrm{db}$ mice}

As per the digital photographic data, the rate of wound closure was confirmed to be dependent on mouse genotype, with $\mathrm{db} / \mathrm{db}$ diabetic mice healing more slowly than $\mathrm{db} /+$ nondiabetic littermates. Citrate buffer-treated wounds on nondiabetic mice were statistically smaller $(p<0.05)$ than similarly treated wounds on diabetic mice at each time point (Figure 3A). The positive control treatment, Promogran ${ }^{\mathrm{TM}}$, significantly accelerated wound healing in diabetic mice at all time points (Figure 3B). SCIO-469-treated diabetic wounds were also found to be statistically smaller than vehicle-treated wounds at all time points (Figure $3 \mathrm{C})$ : day $2(\mathrm{p}<0.02)$, day 4 ( $p<0.01)$, and day $7(\mathrm{p}<0.01)$. The rate of closure of diabetic wounds treated with SCIO-469 was smaller $(\mathrm{p}<0.01)$ when compared to the vehicle-treated group and superior to the Promogran ${ }^{\mathrm{TM}}$-treated groups. Its superiority over Promogran $^{\mathrm{TM}}$ is statistically not significant (Figure 3D).

\section{SClO-469 reduced wound width}

Histology data revealed that diabetic wounds treated with SCIO-469 had a significantly smaller mean wound width than diabetic wounds treated with citrate buffer $(\mathrm{p}<0.03)$, suggesting that SCIO-469 promoted wound contraction in $\mathrm{db} / \mathrm{db}$ mice (Figure $4 \mathrm{~A}$ ). SCIO-469 was as effective as Promogran $^{\mathrm{TM}}$ and produced wound widths similar to those seen in nondiabetic mice $(\mathrm{db} /+)$ at relevant time points (data not shown).

\section{SCIO-469 accelerated re-epithelialization}

As per the histology data, topical application of SCIO-469 to wounds in diabetic mice resulted in statistically significant increases in wound re-epithelialization relative to the vehicle group ( $\mathrm{p}<0.02$; Figure 4B). SCIO-469 effects were comparable to those seen with Promogran ${ }^{\mathrm{TM}}$ and simulated re-epithelialization patterns of nondiabetic mice (data not shown).

\section{SClO-469 increased granulation}

Histological analysis showed that treatment of diabetic wounds with SCIO-469 increased formation of granulation tissue relative to the vehicle-treated group at day 7 


\section{A}
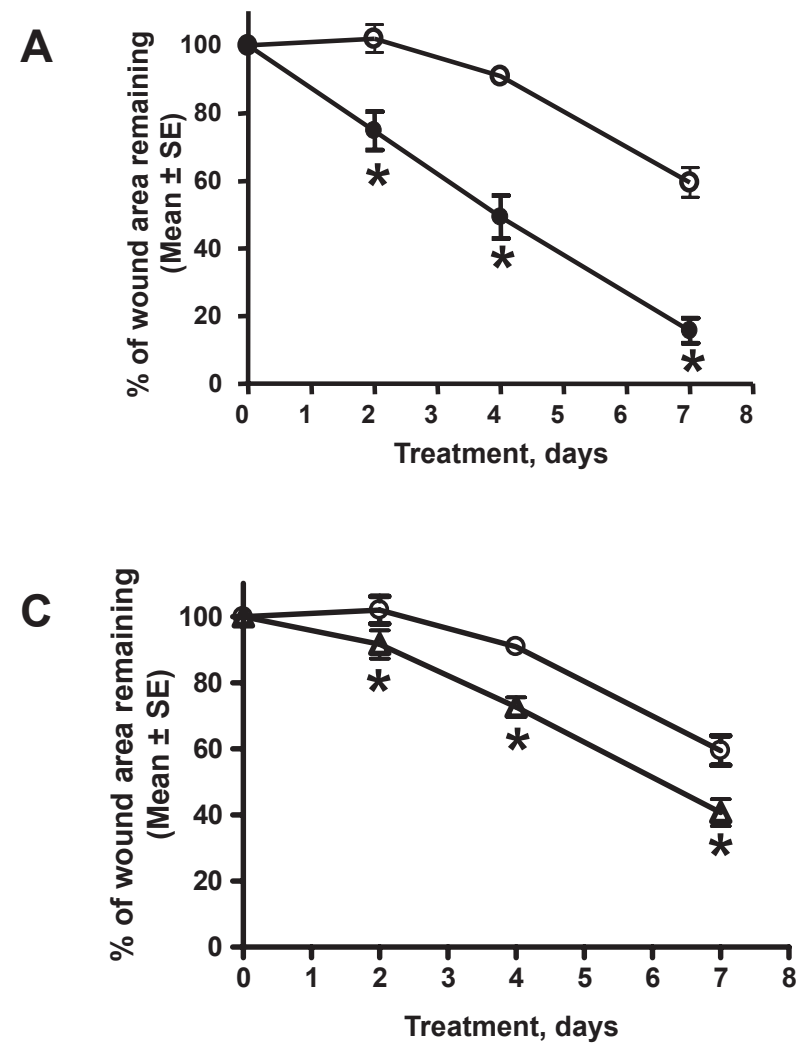

B

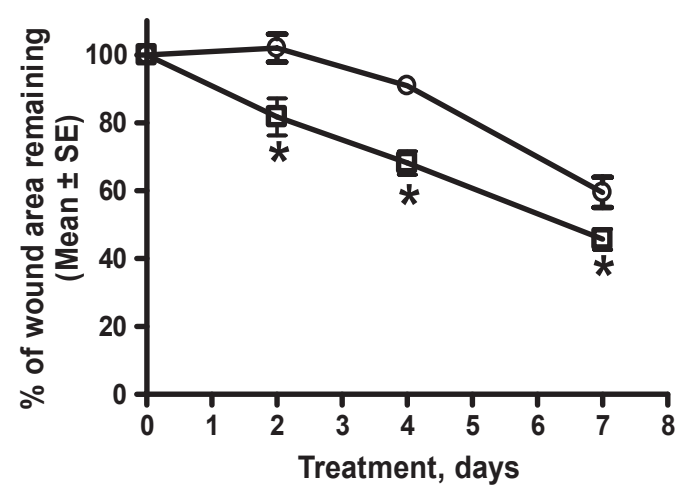

D

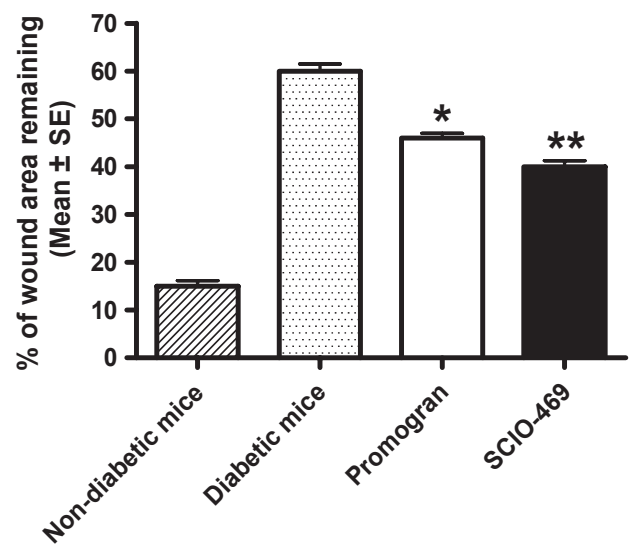

Figure $3 \mathrm{SClO}-469$ accelerated wound healing in $\mathrm{db} / \mathrm{db}$ mice. (A) Digital photographic imaging data showed that wound healing was significantly (*p $<0.00 \mathrm{I}$ ) impaired in the diabetic $\mathrm{db} / \mathrm{db}$ mice (open circles) when compared to the nondiabetic $\mathrm{db} /+$ mice (filled circles): (B) Establishing the suitability of this model. Promogran ${ }^{\mathrm{TM}}$ (open squares) significantly $(* \mathrm{p}<0.05)$ accelerated wound healing in $\mathrm{db} / \mathrm{db}$ mice at all time points when compared with the db/db mice (vehicle-treated group) (open circles); (C) SCIO-469 (open triangles) significantly ( ${ }^{\mathrm{p}}<0.0 \mathrm{I}$ ) accelerated wound closure in $\mathrm{db} / \mathrm{db}$ mice at all time points when compared to the vehicle-treated group (open circles); (D) SCIO469-treated $\mathrm{db} / \mathrm{db}$ wounds (solid bar) were significantly smaller (ie, reduced $\%$ of wound area remaining) on day 7 (**p $<0.0 \mathrm{I}$ ) when compared to the vehicle treated group (dotted bar) and superior to the Promogran ${ }^{\mathrm{TM}}$-treated group ( ${ }^{*} \mathrm{p}<0.05$ when compared to the vehicle-treated group) (open bar). The hatched bar represents wound healing in nondiabetic mice. Values are reported as the mean $\pm \mathrm{SE} ; \mathrm{n}=8$.

(Figure 4C), and was comparable to effects seen with Promogran ${ }^{\mathrm{TM}}$ treatment, with similar granulation levels as those seen in nondiabetic mice.

\section{SClO-469 reduced inflammatory}

cell infiltration into the wound

Histological analysis also showed that treatment of diabetic wounds with Promogran ${ }^{\mathrm{TM}}$ had no impact on cellular maturity within wound tissues compared to vehicle treatment alone. Promogran $^{\mathrm{TM}}$ did not appear to modulate inflammatory or proliferative cell presence within diabetic wounds. In contrast, topical application of SCIO-469 to diabetic wounds was associated with a significant increase in proliferative cells over inflammatory cells as compared to vehicle $(\mathrm{p}<0.02)$ or Promogran ${ }^{\mathrm{TM}}$ $(\mathrm{p}<0.01)$ treatments (Figure 4D); these data are similar to those collected from nondiabetic mice (data not shown).

The gross observational data collected on wound healing (degree of inflammation, edema, erythema, induration, amount of exudate, wound-bed environment, and re-injury/ secondary wounds) (data not shown) supported the significant improvements in wound width, re-epithelialization, granulation tissue formation, and wound maturity seen with topical application of SCIO-469 compared to vehicle alone.

\section{Discussion}

In this study, we confirm results showing that citrate buffer-treated wounds healed significantly more slowly in $\mathrm{db} / \mathrm{db}$ mice than in similarly treated wounds of nondiabetic littermates $(\mathrm{db} /+)$, and confirmed that Promogran ${ }^{\mathrm{TM}}$ treatment accelerated wound closure in diabetic $\mathrm{db} / \mathrm{db}$ mice. Next, we measured levels of the phosphorylated (activated) form of p38 in the presence and absence of the p38 $\alpha$ MAPK-selective inhibitor, SCIO-469, in the skin for a period of 7 days post-wounding. Phosphorylated p38 was present after wounding, with peak levels on days 1 and 2, declining to near baseline by day $7 \mathrm{in} \mathrm{db} / \mathrm{db}$ mice with sustained 
A

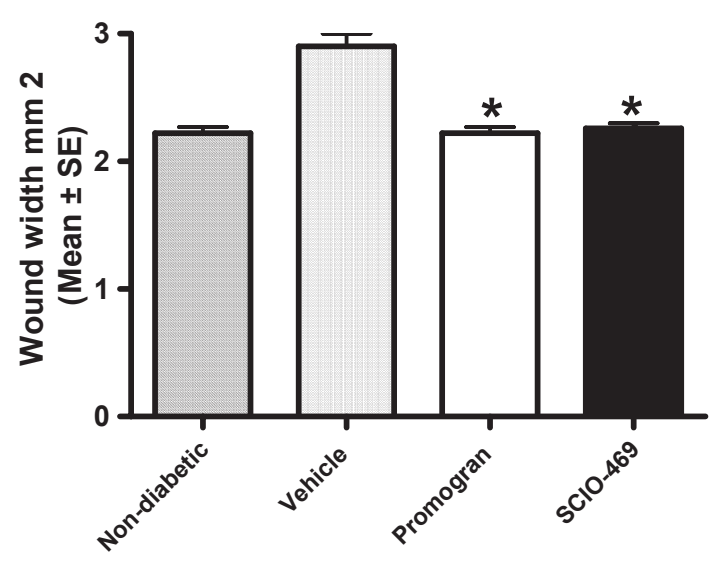

C

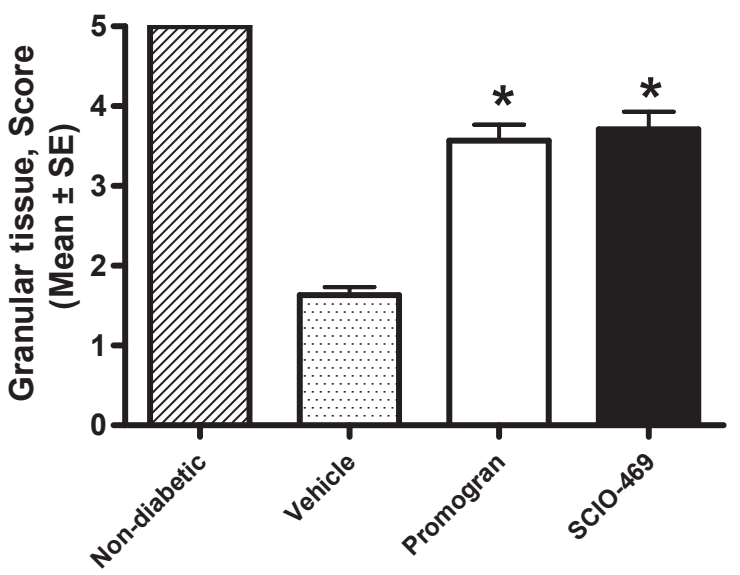

B

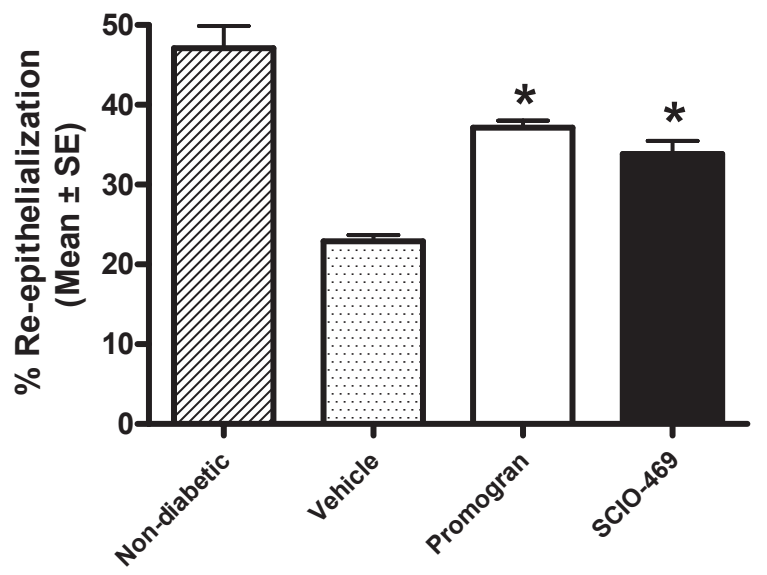

D

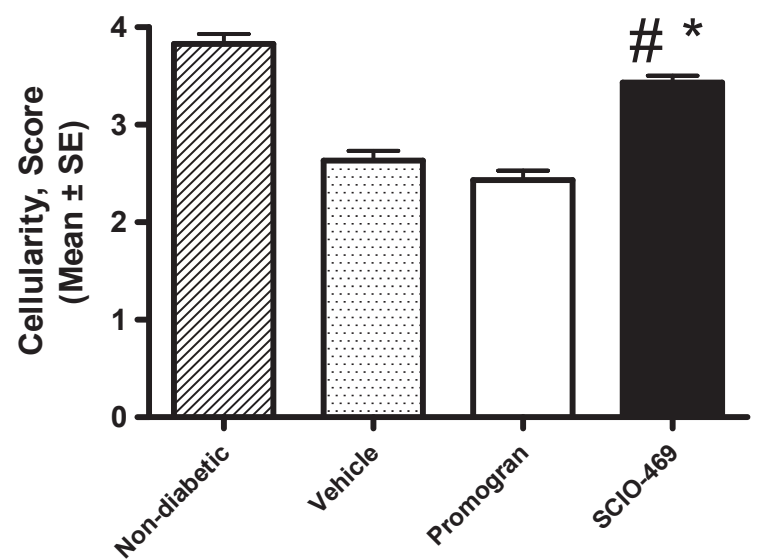

Figure 4 Histological assessments of wound healing. Nondiabetic mice (hatched bars), vehicle-treated db/db mice (dotted bars), Promogran ${ }^{\mathrm{TM}}$-treated $\mathrm{db} / \mathrm{db}$ mice (open bars), $\mathrm{SClO}-469$-treated db/db mice (solid bars). Like Promogran ${ }^{\mathrm{TM}}, \mathrm{SClO}-469$ significantly $\left({ }^{*} \mathrm{p}<0.03\right.$ ) accelerated wound healing by decreasing wound width (A), increasing percent of re-epithelialization (B; $\left.{ }^{*} \mathrm{p}<0.02\right)$ and increasing granular tissue formation $\left(\mathbf{C} ;{ }^{*} \mathrm{p}<0.02\right)$ when compared to the vehicle-treated group. Unlike Promogran ${ }^{\mathrm{TM}}$, SCIO-469 also significantly increased wound maturity/cellularity (D) ie, prevalence of proliferative cells over inflammatory cells (\#p $<0.02)$ and it is statistically significant when compared to the Promogran ${ }^{\mathrm{TM}}$ group $\left({ }^{*} \mathrm{p}<0.0 \mathrm{I}\right)$ Values are reported as the mean $\pm \mathrm{SE} ; \mathrm{n}=8$.

hyperglycemia. In contrast, phosphorylated p38 was not present at any detectable levels on any day in lean litter mates (nondiabetic mice) (Medicherla, unpublished results, 2006).

SCIO-469 accelerated wound healing when applied topically and was associated with significantly lower peak levels of phosphorylated p38 (day 2). The current studies do not differentiate between reduced levels of total p38 and/or reduced proportion of p38 which is phosphorylated (activated). Histological studies showed that SCIO-469 treatment decreased wound width and increased granulation tissue formation and re-epithelializaiton by the end of the study (day 7 post-wounding). These outcomes were comparable or superior to those obtained with Promogran ${ }^{\mathrm{TM}}$ treatment. Unlike Promogran ${ }^{\mathrm{TM}}$, application of SCIO-469 to diabetic wounds increased cellular wound maturity: the ratio of proliferative cells over inflammatory cells. Thus, SCIO-469 significantly inhibited infiltration of inflammatory cells into the wound (Figure 4D) which suggests limiting wound inflammation improves wound healing.

Regulation of p38 activation appears to be critical during wound healing in $\mathrm{db} / \mathrm{db}$ mice. Since SCIO-469-mediated inhibition of p38 phosphorylation in neutrophils and macrophages was associated with significant improvements in wound healing, SCIO-469 may accelerate wound healing by blocking the p38 MAPK signaling pathway. This explanation is consistent with our unpublished observations that SCIO-469 significantly decreases neutrophil infiltration into the hemorrhagic skin in a lipopolysaccharide-induced skin inflammation model, and lowers macrophage numbers in a smoke-induced mouse model of chronic obstructive pulmonary disease (COPD) (S. Medicherla, unpublished observations, 2006). Our data do not address the relative 
roles of low-density lipoprotein, ${ }^{26}$ advanced glycation end-products, ${ }^{27}$ free fatty acids, ${ }^{28}$ diacylglycerol, ${ }^{29,30}$ heat shock protein-27, ${ }^{15,30}$ tumor growth factor- $\beta,{ }^{30}$ or macrophagederived $\mathrm{TNF}^{31}$ in this model. It is possible that one, many, or all of these factors together can activate the p38 MAPK pathway, and that SCIO-469 treatment may inhibit the effects of these agents on inflammatory responses and delayed wound healing. The data in the present study suggest that SCIO-469 inhibits nonresolving inflammation in diabetic wounds via the p38 MAPK signaling pathway. This is an anti-inflammatory action not seen or expected with Promogran ${ }^{\mathrm{TM}}$. The results suggest that SCIO-469 may be a superior therapeutic agent to manage wounds in those with impaired healing ability and may be a useful addition to Promogran ${ }^{\mathrm{TM}}$ therapy.

In summary, we report that SCIO-469, an $\alpha$-selective p38 MAPK inhibitor, accelerates wound healing by inhibiting nonresolving diabetes-induced inflammation in a $\mathrm{db} / \mathrm{db}$ mouse model of impaired wound healing. These results may have bearing on current prophylactic and therapeutic protocols for treating wounds in types 1 and 2 diabetics and in other pathological conditions in which nonresolving inflammation is a primary feature.

\section{Disclosure}

The authors report no conflicts of interest in this work.

\section{References}

1. Yue DK, Swanson B, McLennan S, Marsh M. Abnormalities of granulation tissue and collagen formation in experimental diabetes. Diab Med. 1986;3:221-225.

2. Bitar MS, Ziad N, Labbad N. Transforming growth factor beta and insulin-like growth factor-1 in relation to diabetes-induced impairment of wound healing. J Surg Res. 1996;61:113-119.

3. Waugh HV, Sherratt JA. Macrophage dynamics in diabetic wound dealing. Bull Math Biol. 2006;68:197-207.

4. Liu R, Bal HS, Desta T, Behl Y, Graves DT. Tumor necrosis factor-alpha mediates diabetes-enhanced apoptosis of matrix-producing cells and impairs diabetic healing. Am J Pathol. 2006;168:757-764.

5. O'Connor JC, Johnson DR, Freund GG. Psychoneuroimmune implications of type 2 diabetes. Neurol Clin. 2006;24:539-559.

6. Goren I, Kampfer H, Podda M, Pfeilschifter J, Frank S. Leptin and wound inflammation in diabetic ob/ob mice: differential regulation of neutrophil and macrophage influx and a potential role for the scab as a sink for inflammatory cells and mediators. Diabetes. 2003;52:2821-2832.

7. Pinto FA, Malucelli BE. Inflammatory infiltrate, VEGF, and FGF-2 contents during corneal angiogenesis in STZ-diabetic rats. Angiogenesis. 2002;5:67-74.

8. Goren I, Muller E, Pfeilschifter J, Frank S. Severely impaired insulin signaling in chronic wounds of diabetic ob/ob mice: a potential role of tumor necrosis factor-alpha. Am J Pathol. 2006;68:765-777.

9. Fahey TJ, Sadaty A, Jones WG, Barber A, Smoller B, Shires GT. Diabetes impairs the late inflammatory response to wound healing. J Surg Res. 1991;50:308-313.

10. Norman MU, Hickey MJ. Mechanisms of lymphocyte migration in autoimmune disease. Tissue Antigens. 2005;66:163-172.
11. American Diabetes Association. Diabetes 2002 Vital Statistics. Alexandria, VA: American Diabetes Association; 2002.

12. Hinchliffe RJ, Valk GD, Apelqvist J, et al. A systematic review of the effectiveness of interventions to enhance the healing of chronic ulcers of the foot in diabetes. Diabetes Metab Res Rev. 2008:S119-S144.

13. Matos TJ, Duarte CB, Goncalo M, Lopes MC. DNFB activates MAPKs and upregulates CD40 in skin-derived dendritic cells. J Dermatol Sci. 2005;39:113-123.

14. Hildesheim J, Awwad RT, Fornace AJ Jr. p38 mitogen-activated protein kinase inhibitor protects the epidermis against the acute damaging effects of ultraviolet irradiation by blocking apoptosis and inflammatory responses. J Invest Dermatol. 2004;122:497-502.

15. Medicherla S, Protter AA, Ma JY, et al. Preventive and therapeutic potential of $\mathrm{p} 38$ alpha-selective mitogen-activated protein kinase inhibitor in nonobese diabetic mice with type 1 diabetes. J Pharmacol Exp Ther. 2006;318:99-107.

16. Medicherla S, Ma JY, Mangadu R, et al. A selective p38 alpha mitogen activated protein kinase inhibitor reverses cartilage and bone destruction in mice with collagen induced arthritis. J Pharmacol Exptl Ther. 2006;318:132-141.

17. Nguyen AN, Stebbins EG, Henson M, et al. Normalizing the bone marrow microenvironment with $\mathrm{p} 38$ inhibitor reduces multiple myeloma cell proliferation and adhesion and suppress osteoclast formation. Exp Cell Res. 2006;312:1909-1923.

18. Navas TA, Mohindru M, Estes M, et al. Inhibition of over activated p38 MAPK can restore hematopoiesis in myelodysplastic syndrome progenitors. Blood. 2006;108:4170-4177.

19. Ohura N, Kurita T, Takushima A, Shibata M, Harii K. Efficacy of skin-protection powder for use as a dressing intractable ulcers. $J$ Wound Care. 2006;15:471-476.

20. Toyama T, Ohura N, Kurita M, Momosawa A, Harri K. Effectiveness of short-contact topical tretinoin in promoting wound healing in $\mathrm{db} / \mathrm{db}$ mice. Scand J Plast Reconstr Surg Hand Surg. 2006;40:329-334.

21. Hart J, Silcock D, Gunnigle s, Cullen B, Light ND, Watt PW. The role of oxidized regenerated cellulose/collagen in wound repair: effects in vitro on fibroblast biology and in vivo in a model of compromised healing. Int J Biochem Cell Biol. 2002;34:1557-1570.

22. Lobmann R, Zemlin C, Motzkau M, Reschke K, Lehnert H. Expression of matrix metalloproteinases and growth factors in diabetic foot wounds treated with a protease absorbent dressing. J Diabetes Complications. 2006;20:329-335.

23. Kumar S, McDonnell PC, Gum RJ, Hand AT. Novel homologues of CSBP/p38 MAP kinase: activation, substrate specificity and sensitivity to inhibition by pyridinyl imidazoles. Biochem Biophys Res Commun. 1997;235:533-538.

24. Stvensson CI, Medicherla S, Malkmus S, et al. Spinal and DRG p38 MAP kinase in osteosarcoma pain model. Pharmacol Biochem Behav. 2008;90:664-675.

25. Vanderkerken K, Medicherla S, Coulton L, Protter AA, Higgins LS, Croucher PI. Inhibition of p38 MAPK prevents the development of myeloma bone disease, reduces tumor burden and increases survival in murine models of myeloma, Cancer Res. 2007;67:4572-4577.

26. Dobreva I, Waeber G, James RW, Widmann C. Interleukin-8 secretion by fibroblasts induced by low density lipoproteins is p38 MAPK dependent and leads to cells spreading and wound closure. J Biol Chem. 2006;281:199-205.

27. Alikhani M, Maclellan C, Raptis M, Vora S, Trackman P, Graves D. Advanced glycation end products induced apoptosis in fibroblasts through activation of ROS, MAP kinases and FOXO1 transcription factor. Am J Physiol Cell Physiol. 2007;292:C850-856.

28. Collins QF, Xiong Y, Lupo EG, Liu HY, Cao W. p38 mitogen-activated protein kinase mediates free fatty acid-induced gluconeogenesis in hepatocytes. J Biol Chem. 2006;281:24336-24344.

29. Mansfied PJ, Hinkovska-Galcheva V, Carey SS, Shayman JA, Boxer LA. Regulation of polymorphonuclear leukocyte degranulation and oxidant production by ceramide through inhibition of phospholipase D. Blood. 2002;99:1434-1441. 
30. Hirano S, Rees RS, Gilmont RR. MAP kinase pathways involving hsp27 regulates fibroblast-mediated wound contraction. J Surg Res. 2002;102:77-84.
31. Yavuz D, Tugtepe H, Cetinel S, et al. Collagen ultra structure and TGF beta1 expression preserved with aminoguanidine during wound healing in diabetic rats. Endocr Res. 2005;31:229-243.

\section{Publish your work in this journal}

Diabetes, Metabolic Syndrome and Obesity: Targets and Therapy is an international, peer-reviewed open-access journal committed to the rapid publication of the latest laboratory and clinical findings in the fields of diabetes, metabolic syndrome and obesity research. Original research, review, case reports, hypothesis formation, expert opinion and commentaries are all considered for publication. The manuscript management system is completely online and includes a very quick and fair peer-review system, which is all easy to use. Visit http://www.dovepress.com/testimonials.php to read real quotes from published authors.

Submit your manuscript here: http://www.dovepress.com/diabetes-metabolic-syndrome-and-obesity-targets-and-therapy-journal 